\title{
Land Tenure Reform in Three Former Settler Colonies in Southern Africa
}

\author{
Chizuko Sato
}

\begin{abstract}
This study explores the challenges of land tenure reform for three former settler colonies in southern Africa-Zimbabwe, Namibia, and South Africa. While land redistribution programmes have been the primary focus of land reform for these countries since independence, land tenure reform for the inhabitants of communal areas is an equally important and complex policy challenge. Before independence, the administration of these areas was more or less in the hands of traditional leaders, whose roles were sanctioned by the colonial and apartheid authorities. Therefore, one of the primary concerns with respect to reforming land tenure systems in communal areas is related to the power and authority of traditional leaders in the post-independence period. This study highlights striking similarities in the nations' land tenure reform policies. All of them gave statutory recognition to traditional leaders and strengthened their roles in rural land administration. In understanding this 'resurgence' or tenacity of traditional leadership, the symbiotic relationship between the ruling parties and traditional leaders cannot be ignored and should be problematised. Nonetheless, this chapter also argues that this obsession with traditional leadership may result in the neglect of other important issues related to land tenure reform in communal areas, such as the role of customary land tenure as social security.
\end{abstract}

Keywords Land tenure reform • Traditional leadership • Namibia • Zimbabwe • South Africa

\section{Introduction}

Three former settler colonies in southern Africa-Zimbabwe, Namibia, and South Africa-introduced land reform soon after they gained independence in the 1980s and the 1990s. The principal focus of their land reform policies was land redistribution, which aimed to dismantle the racially skewed land ownership structure moulded by

\author{
C. Sato $(\bowtie)$ \\ Institute of Developing Economies, JETRO, Chiba, Japan \\ e-mail: chizuko_sato@ide.go.jp
}


settler colonialism and the apartheid regime (Odendaal 2010; Scoones et al. 2010; Moyo 2013; Aliber et al. 2013). Nevertheless, land tenure reform was also significant for these countries due to at least three reasons. First, land tenure reform in the areas reserved for the black population during the colonial and apartheid periods was also an essential component of their land reform policies. This aspect of land reform has turned out to be equally, if not more, complex and challenging as land redistribution. Second, the question of what form of land tenure should be introduced to the land given to the black population through land redistribution programmes after independence has also been a substantial policy challenge for these three countries. Third, a significant proportion of the rural population still resided in the areas where land tenure reform was to be implemented in Zimbabwe and Namibia. This is also the case in South Africa, albeit to a lesser extent.

While the land redistribution policies of these three southern African countries were often discussed together in order to identify their similarities and possible mutual influences (Hall 2003; Zondi 2003; Moyo 2007; Mkodzongi 2018), their land tenure policies have rarely been compared in the literature on land reform in southern Africa. This study aims to fill this gap by discussing their land tenure reform policies after independence from a comparative perspective. This exercise will highlight the common challenges faced by these three southern African countries in consolidating the land rights of people living under customary land tenure and reforming the institution that manages communally held resources. It will also illuminate how this land tenure system and its accompanying structure of authority (traditional leaders) have historically played an indispensable role in the development of a settler economy in these nations. Reforming the customary land tenure system touches upon the fundamental features of the political economy of these countries (Murombedzi 2010).

This chapter first summarises the characteristics of the land tenure system applied to the areas reserved for the black population during the colonial and apartheid periods in these three southern African countries. These areas were first called 'native reserves' and were followingly renamed 'homelands' (Bantustans) in Namibia and South Africa and 'tribal trust lands' in Zimbabwe in the twentieth century. Since independence, they have been called 'communal areas/lands'. Next, this chapter reviews the land tenure reform policies that were introduced after independence in order to highlight the similarities and differences in their identification of the problems of existing land tenure systems in communal areas and their selection of measures to address them. In the final section, this chapter discusses the salient features that have emerged in the formation and implementation of land tenure reform policies in these three countries-particularly addressing the growing role of traditional leaders in rural land governance and its implications. 


\section{Types of Land Tenure in Three Former Settler Colonies in Southern Africa}

What distinguishes these three countries from other sub-Saharan African countries in terms of land issues is the extensive degree of land that was taken from their black populations during the colonial and apartheid periods. As summarised in Table 1, while the degree of land dispossession in these three countries also differs-with the dispossession in South Africa being the most extensive and that in Namibia being the least - these numbers are much higher in comparison to other former nonsettler colonies in southern Africa, such as Malawi and Botswana. The colonial land dispossession created a dualism in land tenure system in these three countries, as land that was taken by white settlers is held in freehold tenure, whereas land reserved for the black population is kept in so-called customary, communal, or tribal land tenure. This latter form of land tenure is similar to those found in several African countries and has two principal characteristics.

One is the multi-layered nature of land rights, and the other is that these rights are conferred to the land's residents based on their membership in a particular group/community, usually centred on chieftaincy or ethnic belonging. In most cases, the legal title holder of customary land is either the state, a parastatal entity, or the head of the state. However, the land's residents have a series of long-established customary rights. These rights include the right to a household plot to build dwellings, cultivate fields, and graze livestock. Their rights to land are different from those of legal rights holders and freehold tenures. For example, it is usually impossible for them to receive loans from financial institutions by using land as collateral. However, once residential land and fields are allocated to certain individuals/households, these lands are considered to belong to these individuals/households, provided that they are in use. Land can also be inherited by family members (Bennett 2004; Sato 2018a).

Table 1 Forms of land tenure in certain southern African countries

\begin{tabular}{|c|c|c|c|c|c|}
\hline & \multirow[t]{2}{*}{$\begin{array}{l}\text { Year of } \\
\text { independence }\end{array}$} & \multirow{2}{*}{$\begin{array}{l}\text { Land taken } \\
\text { from native } \\
\text { population by } \\
1957 \text { (\% of } \\
\text { national area) }\end{array}$} & \multicolumn{3}{|c|}{$\begin{array}{l}\text { Types of land tenure and its coverage (\% of } \\
\text { national area) in } 1999\end{array}$} \\
\hline & & & $\begin{array}{l}\text { Freehold or } \\
\text { leasehold }(\%)\end{array}$ & $\begin{array}{l}\text { Customary, } \\
\text { communal, or } \\
\text { tribal land }(\%)\end{array}$ & $\begin{array}{l}\text { State land and } \\
\text { protected } \\
\text { areas }(\%)\end{array}$ \\
\hline Zimbabwe & 1980 & 49 & 34 & 41 & $25^{\mathrm{a}}$ \\
\hline Namibia & 1990 & 44 & 44 & 43 & 13 \\
\hline South Africa & 1994 & 89 & 72 & 14 & 14 \\
\hline Malawi & 1964 & 5 & 13 & 69 & 18 \\
\hline Botswana & 1966 & 6 & 4 & 70 & $26^{\mathrm{b}}$ \\
\hline
\end{tabular}

Source Adopted from Adams and Knight (2012, 28-29)

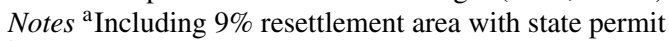

${ }^{\mathrm{b}}$ Including land held in fixed period state grants (a form of lease) in larger towns for residential and business purposes 
Before independence, the administration of these customary lands was more or less in the hands of traditional leaders, whose roles were sanctioned by the colonial and apartheid authorities. While these traditional leaders drew their legitimacy from the traditions and customs of local African societies, their roles have changed since colonisation, especially through the system of indirect rule. In southern Africa, this system was originally introduced in the British Natal colony in the mid-nineteenth century. It was then applied nationwide in South Africa through the Native Administration Act (1927) after the Union of South Africa was formed in 1910 (Mamdani 1996; Ntsebeza 2005). The Act recognised the status of traditional leaders, but turned them into local administrative officers of the government. It also gave the Minister of Native Affairs the authority to create a new 'tribe' or divide the existing 'tribe' and to appoint and dismiss chiefs and headmen (Peires 2014, 15-16). After the National Party came to power in 1948, the Bantu Authorities Act (1951) was enacted, which enabled traditional leaders to act as local governments in their homelands under the name of 'tribal authority' (Sato 2000).

Although Namibia had a system of indirect rule similar to that of South Africa because it was effectively ruled by the South African administration after the end of the First World War (Lankhorst 2009, 198-199), the situation was slightly different in Zimbabwe-where traditional leaders were first deprived of their authority to allocate land by the colonial government through the Native Land Husbandry Act (1951). This Act aimed to introduce a system of individual land tenure in native reserves in order to convert rural 'tribesmen' and urban migrants into full-time farmers and workers. However, the rural modernisation policy pursued through this Act turned out to be unpopular. In particular, the labour-intensive conservation work and forced reduction of livestock that were implemented under this policy led to increased rural protests. Urban migrant workers who lost their rights to land in their native reserves were increasingly attracted to the cause of African nationalism. Faced with mounting rural unrest and resistance, the colonial government decided to transfer power and authority back to traditional leaders in order to recover political stability in the native reserves. In the 1960s, several measures and programmes to co-opt traditional leaders were introduced, including the Tribal Trust Land Act (1967), which restored the power to allocate land to traditional leaders (Andersson 1999, 560-565; Mbiba 2001, 428-431). The intensification of guerrilla wars in the region in the late 1970s resulted in the traditional leaders that served the Rhodesian state being deemed as enemies and traitors by the guerrilla fighters. Several chiefs were either killed, captured, or forced to flee to the cities, whereas others joined the nationalist movement (Alexander 2006, 2018). 


\section{Land Tenure Reform Policy After Independence and Its Contestations}

Since the 1990s, the strengthening of rural residents' land rights under the customary land tenure system has become an important policy issue in many African countries (Bruce and Knox 2009). In many countries, it took the form of land law reform, and most countries chose one of the following two policy options. One was to establish a new state entity, known as land boards, to administer land at a local level. This measure was introduced in countries such as Botswana and Namibia. The other was to strengthen the role of traditional authorities in local land administration, which was adopted in countries such as Malawi and South Africa. However, this dichotomy is also misleading with respect to southern Africa, as traditional leaders often maintained influence on local land boards in Namibia, and the consolidation of the land allocation power of traditional leaders in democratic South Africa was a highly contested process (Sato 2018a).

\subsection{Zimbabwe}

Zimbabwe obtained independence from Britain and its settler-rule in 1980 through the Lancaster House Agreement, which set the foundational principles of its land redistribution programme for the first ten years of its independence. With regard to land tenure reform, the newly independent government enacted the Communal Land Act (1982), which repealed the Tribal Trust Land Act (1979) and renamed tribal trust land as communal land (Cheater 1990, 201). The Act also transferred the power to allocate land in communal areas from customary chiefs to the elected rural district councils that were established by the District Councils Act (1980). This Act also introduced the village development committees (VIDCOs) and the ward development committees (WADCOs) as representative bodies for the residents of communal areas. These elected local representative institutions were expected to implement the rural modernisation programmes of the central government (Alexander 2018). Some customary chiefs voiced opposition to these new policy measures (O'Flaherty 1998, 539-540), but the ruling Zimbabwe African National Union-Patriotic Front (ZANUPF) government crushed these oppositional voices. Nonetheless, many academic studies have reported that traditional leaders, especially village heads (sabhukus), ${ }^{1}$ continued to allocate land and mediate local land disputes in many communal areas (Cousins et al. 1992, 16; O'Flaherty 1998, 547-550; Andersson 1999, 555-556).

\footnotetext{
${ }^{1}$ Sabhuku literally means 'book-keeper' as the village head became the holder of the tax register during the colonial period (Anderssen 1999, 557). It is a customary leader at the village level and is sometimes translated as sub-headman in English literature. However, according to Alexander $(2006,135)$, in Matabeleland, sabhuku was a colonial invention and was not regarded as a legitimate customary institution at the time of independence.
} 
The government significantly altered its course in the late 1990s, after the Commission of Inquiry into Land Tenure recommended the dissolution of the VIDCOs and WADCOs due to their ineffectiveness in contributing to the development of communal areas. The Commission also recommended enhancing the administrative powers of the traditional authorities in communal areas instead of bestowing power upon locally elected entities. In line with these recommendations, the Traditional Leaders Act (1999) was enacted, which officially restored the power to allocate land in communal areas to customary chiefs. However, their decisions had to be approved by the rural district councils. The Act also abolished the elected VIDCOs and the chiefs appointed sabhukus to lead 'village assemblies' in their place (Chimhowu and Woodhouse 2010, 19-20). The 2002 amendment to the Communal Land Act (1982) ascribed authority to the rural district council, but it also stated that the council should consult and cooperate with the chief that is appointed to preside over the community as per the Traditional Leaders Act (Murisa 2013, 255-257).

Since 2000, Zimbabwe's land sector has undergone a complete overhaul through the implementation of a new land reform policy - the Fast Track Land Reform Programme (FTLRP). The origin of the FTLRP was in the land occupation movements led by war veterans in 1999, who had fought in the war to achieve liberation from white Rhodesia. The period of land occupation and confusion that preceded the FTLRP is known as jambanja. Given the unprecedented level of demand for land redistribution and the emergence of strong political opposition that originated from trade union movements among urban workers in the late 1990s, which resulted in the formation of the Movement for Democratic Change (MDC), the ZANU-PF government decided to assume control of the land occupation movements and incorporated them into its land reform policy (Gideon 2019, 14-16).

The principal significance of the FTLRP undoubtedly lies in the fact that it has successfully dismantled the racially skewed land ownership structure that was moulded by colonial rule. At the time of independence in 1980, more than 15 million ha of land were devoted to large-scale commercial farming at the hands of approximately 6000 farmers, who were predominantly white. By 1999, the white commercial farming area was reduced to 12 million ha, which was approximately $35 \%$ of the total agricultural land (Scoones et al. 2010, 2-3). The government appropriated more than nine million ha of white-owned farmland for the FTLRP (Chimhowu and Woodhouse 2010, 14; Moyo 2013, 42). Simultaneously, it is also important to stress that the FTLRP created a new dual structure, which consists of A1 resettlement farms and A2 commercial farms. The former are small-scale, permit-based lands, whereas the latter are medium-scale farms with leasehold tenure (Scoones et al. 2010, 3-4; Chimhowu and Woodhouse 2008, 286-287, 2010, 14; Moyo 2013, 45).

While the FTLRP was essentially a land redistribution policy, it also brought the land tenure policy to the fore with regard to who would oversee the land allocation process on the A1 resettlement farms. Initially, the war veterans controlled the land occupation movements in the sense that they selected farms to occupy and mobilised people to occupy the farms. However, traditional leaders were also involved in the land occupation process, especially with respect to identifying ancestral lands and 
conducting cleansing ceremonies after the occupation. Moreover, once the ZANUPF government took over the process and formalised it as the FTLRP, traditional leaders such as chiefs and village heads (sabhukus) were given bigger roles, which included the selection of the beneficiaries and the allocation of land on the A1 resettlement farms. In 2003, the government announced that both the Rural District Council Act and Traditional Leaders Act were to be applied in these areas (Murisa 2013, 261$269,2014)$. Through this process, some chiefs were able to expand the territories under their jurisdiction by putting their people on the farms meant for A1 resettlements that were adjacent to communal areas under their jurisdiction (Mkodzongi 2016).

Moreover, the FTLRP unleashed the land restitution demands/claims made by several chiefs based on historical land dispossession that had taken place during the colonisation process (Fontein 2009; Dande and Mujere 2019). The demands for the restitution of land dispossessed during colonisation by traditional leaders existed even prior to Zimbabwe's independence. However, the ZANU-PF government never met these demands in the 1980s and the 1990s, when it resettled people on farms that it had bought with financial assistance from Britain (Chamunogwa 2019, 74). Unlike South Africa, Zimbabwe's land redistribution programme did not have an element of land restitution. This implicit rule in the Zimbabwean land redistribution policy was broken during the FTLRP, as some chiefs led people to occupy specific farms that had historically belonged to their tribes but were subsequently lost to white settlers during the colonial period, and their occupations were formalised through the A1 resettlement process (Chimhowu and Woodhouse 2008, 296-297; Fontein 2009). It has also been reported that disputes over traditional boundaries have emerged in certain areas due to the FTLRP, as different chiefs decided to resettle their people on the same A1 resettlement farm (Mkodzongi 2016; Dande and Mujere 2019).

Thus, several studies emphasise the significant roles played by traditional leaders during the jambanja period and the subsequent FTLRP, highlighting the personal and tribal intentions governing their acts (Chimhowu and Woodhouse 2008, 296297; Fontein 2009; Mkodzongi 2016; Dande and Mujere 2019; Chamunogwa 2019). Nevertheless, the extent to which traditional leaders had complete autonomy in their actions is disputed. Alexander $(2018,151)$ argues that during the FTLRP, traditional leaders were 'influential only insofar as they subordinated themselves to the ZANU-PF's partisan project' on resettlement farms. Despite the FTLRP's unprecedented achievements with respect to responding to the popular demand for land and dismantling the colonial land ownership structure, Gideon $(2019,21)$ is also adamant that it was the ZANU-PF's 'exclusive partisan programme' and not the 'non-partisan national initiative' that it claimed to be. He states that the 'ZANU-PF structures mutated with land committees and local community leadership at every level' in the implementation of the FTLRP.

While the FTLRP enabled black people to resettle in formerly white farms, some communal areas experienced an influx of people from urban areas and white farms throughout the 1990s and the early 2000s. This increased the scarcity of land in communal areas and prompted informal land transactions that were prohibited by 
the law (Chimhowu and Woodhouse 2008, 2010; Goodwin 2013). 'Private' transactions of land in communal areas were already reported in the 1980s (Cousins et al. 1992, 17-18), and these practices seem to have become more common since then. Chimhowu and Woodhouse $(2008,2010)$ discussed the development of two forms of commodification of land in the Svosve communal lands in Marondera district in Mashonaland East province in the mid-2000s. One was the sale of grazing land by sabhukus to newcomers who sought residential and agricultural lands. The other was the leasing out of agricultural lands by absentee residents who lived in the cities, resettlement farms, or overseas as diaspora, and their relatives. However, in both the 1980 s and the 2000s, these land transactions were mediated by customary authorities and therefore did not necessarily undermine the customary land tenure system. In the context of the lack of security of these informal land transactions, Goodwin (2013) illustrated how land purchasers tried to strengthen their land rights by creating and reinforcing their connection with the land through traditional ceremonies and practices.

\subsection{Namibia}

Namibia obtained independence from South Africa in 1990. The scope of Namibia's land reform policy was discussed at the National Land Conference that was held in Windhoek in 1991, in which 700 people participated (Adam and Knight 2012, 36). Although Namibia also experienced a much higher degree of land dispossession in comparison to other African countries, the extent of dispossession in Namibia was still the least among the three former settler colonies in southern Africa.

Namibia's colonial land dispossession had unique geographical and ethnic dimensions. The colonial land dispossession in Namibia took place through the German conquest in the late nineteenth century in the middle and southern parts of the country, where the Herero and Nama ethnic groups lived. The German colonial authority named the conquered areas the 'police zone', and this area was maintained exclusively for white settlements even after the First World War, when Namibia (known as South West Africa at that time) became a British protectorate administered by South Africa. The Herero and Nama people paid a huge price in both their blood and lands during the German conquest and subsequently relocated to native reserves that were established outside the 'police zone'. In contrast, the northern part of the country, where the majority of rural inhabitants lived, was never invaded by colonial settlers. It was set aside as native reserves (later Bantustans) for different ethnic groups, and traditional authorities that were appointed by the colonial government maintained a degree of autonomy in administering them (Werner 1993; Lankhorst 2009, 198199; Amoo and Harring 2012, 223-226). Approximately 40\% of the people lived in one of these reserves, which was known as the Owamboland. Its residents (the Owambo people) became the political foundation of Namibia's liberation movement—-the South West Africa People's Organisation (SWAPO)—which later turned into the ruling party. 
Reflecting these historical specificities, discussions at the National Land Conference in Namibia were dominated by issues related to land tenure reform in communal areas (former Bantustans), rather than the question of how to redistribute whiteowned farms to black people. Half of the recommendations from the conference concerned land issues in communal areas, such as the need to guarantee land to local people, the abolition of land allocation fees, the recognition of land rights for women, the establishment of effective land administration, the prohibition of the 'illegal' fencing of grazing lands, and the encouragement for moving livestock belonging to wealthy farmers to commercial farms. These recommendations were fed into the policy document of the National Land Policy White Paper in 1997 (Adam and Knight 2012, 36).

It took an additional five years before the legislation on land tenure reform in the communal areas was formulated. The Communal Land Reform Act (2002) stipulated that, in accordance with the Constitution, the ownership of rural land in communal areas is vested in the state. The Act also created two different forms of land tenure for the residents of communal areas. One was the customary land right, whereas the other was the 99-year leasehold right. The Act prescribed the establishment of communal land boards as the entity that would administer these land rights. Every individual or family seeking the recognition of their customary land rights must submit an application to a local communal land board that will handle the registration of their customary land rights. Simultaneously, the Act recognised the limited role of traditional authorities in communal land administration. Thus, chiefs have maintained the power to allocate communal land to individuals/families, but their decisions have to be approved by the local communal land boards that will handle the registration process. In this sense, the communal land boards were tasked with supervising the land allocation conducted by chiefs. The Act further recognised that the traditional authorities have the power to regulate grazing access to commonage within their local communities (Lankhorst 2009, 199-201).

Thus, one can say that Namibia introduced a hybrid system for the administration of land in communal areas. In this system, the traditional authorities were expected to work in conjunction with the newly created state entity - the communal land boards. However, who would constitute the traditional authority in this hybrid system became one of the contentions surrounding land administration in communal areas. Prior to the Communal Land Reform Act (2002), the Namibian government enacted the Traditional Authorities Act (2000), which recognised traditional authorities and the traditional communities that they represented. When the traditional leadership of six San communities applied for recognition as a traditional authority under the Traditional Authorities Act (2000), the Namibian government at first turned down all the applications. Later, it recognised the traditional leadership of two San communities that lived in Bushmanland (one of the former Bantustans in the northeast of the country). They are the !Kung and Jul'hoansi communities, who comprise only $15 \%$ of the total San population in Namibia. ${ }^{2}$ Since they do not have any land of their

\footnotetext{
${ }^{2}$ There are 17 San distinct groupings in Namibia. The San people are an indigenous hunter-gatherer group who have resided in southern African region. Being a small minority with a less centralised
} 
own, most San communities whose applications for the recognition of their traditional leadership were rejected by the government continue to live on the land under the authority of the Owambo and Kavango people or on white farms as farmworkers. Since their traditional leadership was not recognised by the government, they are not consulted on matters related to the land they occupy (Lankhorst 2009, 207).

The other highly contentious issue surrounding land administration in Namibia's communal areas is the encroachment of commonage through illegal fencing by wealthy or politically well-connected individuals. This problem of privatisation of commonage through illegal fencing has been exacerbated, particularly since independence, as an increasing number of wealthy black farmers who accumulated wealth in urban economies began to invest in commercial farming in communal areas (Lankhorst 2009, 209-210). According to Gargallo (2020, 134-135), more than 1000 fences were set up in communal areas during the first ten years of the twenty-first century. These amounted to three million ha of fenced ranches. In addition, while $46.4 \%$ of Kavangoland's total land area was used as a communal grazing area, $30 \%$ of it was occupied by commercial ranches. This process was facilitated by the traditional authorities' inability to regulate grazing access to the commonage under their jurisdiction and by the co-optation of traditional authorities by wealthy or politically well-connected farmers. Fencing a part of commonage, especially the most valuable part of the water holes, has reduced people's access to grazing land and water sources. Consequently, it prompted the movement of these excluded people to the commonage of neighbouring communities, which resulted in land conflicts between neighbouring communities (Lankhorst 2009, 209-210).

\subsection{South Africa}

South Africa was the last country among the three discussed here to obtain independence from racial domination. Like Namibia, it held the National Land Conference in which representatives from various corners of the society came to discuss the future direction of land reform policy. The conference was held in 1993, just prior to the country's first democratic elections (National Land Committee 1994). In addition, there were other stakeholder conferences on the future of land reform, such as the one funded by the World Bank, that had some influence on the final land reform policy proposed in the White Paper on Land Policy (hereinafter: the White Paper) published in 1997 (Williams 1996). South Africa's land reform policy was unique, as

political system, the San have historically been the most marginalised people in Namibia. Most of their traditional hunting grounds were seized by white settlers and were converted into commercial farms. The creation of Bushmanland as their homeland occurred much later than homelands for Bantu-speaking people, and most of the San never came to live on this land. As a result, even after independence, most San communities lived on white farms as farmworkers and on former homelands designated for Bantu-speaking ethnic groups in the north-eastern region of Namibia (Lankhorst 2009, 206-208). 
it contained not only a land redistribution programme that aimed to distribute whiteowned farms to black people to redress the racial inequality of land ownership, but also the land restitution programme that aimed to return land to those who had been dispossessed of it by racially discriminatory laws and practices after the Natives Land Act (1913). The White Paper also proposed a land tenure reform programme to consolidate the land rights of residents of the former homelands (also known as Bantustans) and the tenants and dwellers on white-owned farms.

The White Paper identified two problems with the former homelands' land tenure system. One was that residents' rights to the land were not officially recognised, which placed them in a vulnerable state. The other was that the land administration system in the former homelands was in a state of disarray and its tendency to discriminate against women was incompatible with the democratic principles enshrined in the Constitution (DLA 1997, 30-34). As an interim measure, the Interim Protection of Informal Land Rights Act (1996) was enacted to protect the vested interests (land rights) of people who did not have explicit legal rights to the land that they occupied, such as residents of the former homelands. The Act also stipulated that people with informal rights to the land must be treated as stakeholders when such land is subject to development projects and business transactions (DLA 1997, 62). Following the White Paper, the Land Rights Bill was discussed within the Department of Land Affairs, but it was never introduced to Parliament. While South Africa embarked on the land redistribution and land restitution components of its land reform policy soon after its democratisation, it took ten years for the legislation to enforce land tenure reform. Moreover, the Communal Land Rights Act (2004, hereinafter: CLaRA) was never fully implemented after the Constitutional Court declared it unconstitutional in 2010 .

Although the CLaRA was struck down due to procedural reasons, the legal challenge posed to the CLaRA revealed the fundamental contentions surrounding land tenure reform in South Africa. The CLaRA aimed to recognise the various forms of existing land rights - formal and informal, registered or unregistered —of the people residing in communal lands, that is, the former homelands of South Africa. The CLaRA had three principal provisions. First, it proposed two forms of land rights. One was the community/group land rights that were bestowed upon the community and registered under the name of the community. The other was the right to a piece of land within the communal land that was given to individual members of the community and registered under the name of the individual residents. Both land rights could be converted into freehold ownership. Second, it proposed that the community/group land rights were to be administered by a land management committee that had to be established within the community. It also stated that if there is a traditional council within the community, such councils may exercise the authority and obligations of the land management committee. Third, it stipulated the establishment of the Land Rights Board, which was the government agency that would oversee the administration of land by the land management committees (Sato 2018a).

The traditional council is a council established within local municipalities by the Traditional Leadership and Governance Framework Act (2003, hereinafter: TLGFA), 
which gave traditional leaders a wide range of roles that covered agriculture, health, the administration of justice, safety and security, environment, tourism, and so forth. Its predecessor was the tribal authority that was established by the Bantu Authorities Act (1951) of the apartheid era (Cousins 2008, 13). The TLGFA aimed to reform the traditional leaders' administration system by introducing the principles of gender equality and democracy (Williams 2009). ${ }^{3}$ However, not everyone agreed on making the traditional council a land administration committee. Thus, it was the second provision of the CLaRA that led to the legal challenge by those who objected to the traditional council's appropriation of the responsibility of the land administration committee. With the support of land NGOs and activists, four rural communities submitted a legal challenge to the CLaRA in 2006-presenting two oppositional arguments. First, they argued that the CLaRA would weaken people's existing land rights, because whenever a traditional council existed, such councils would become land management committees, which was problematic. Moreover, the CLaRA did not recognise the relative autonomy of communities within the boundaries of traditional councils. Second, they argued that there was a procedural error in the legislation process (Cousins 2008; Murray and Stacey 2008).

Although the CLaRA was found to be unconstitutional due to procedural reasons, the question of how to define the boundaries of the collective/communal land ownership that was raised by this legal case is arguably fundamentally important for reforming the customary land tenure system - where the right to land has been given based on one's membership in the community. If the traditional council were to become the land administration committee, the owner of the communal land would be synonymous with 'tribe'. The four rural communities that challenged the CLaRA claimed that smaller communities within the 'tribe' had relative autonomy (Claassens and Gilfillan 2008; North Gauteng High Court 2009). There are no population statistics for each tribe in South Africa, but Claassens $(2008,265)$ estimated that each tribe/community would consist of approximately 10,000 to 20,000 people. My rough estimate presented a figure of 18,000 persons per chief, ${ }^{4}$ which is almost identical to Claassens's estimate. The size of each tribe differs, but the practicality of establishing a committee that represents more than 10,000 people to administer collectively owned land should be examined regardless.

The legal challenge to the CLaRA also raised the question of whether traditional leaders should have the authority to administer land in the first place. Unlike other African countries, South Africa's former homelands are not the main targets of agricultural foreign direct investment (FDI) by foreign companies. Therefore, the so-called land grabs have not been a major issue yet. However, in areas where mining occurs in the North West Province, it has been reported that traditional leaders

\footnotetext{
${ }^{3}$ The TLGFA stipulated that a third of the councillors should be female and that $40 \%$ of councillors should be democratically elected members of a 'traditional community'. The remaining $60 \%$ consists of 'members of the traditional community' who are chosen by traditional leaders.

4 According to the FFC (2016), as of early 2016, there were 13 kings and paramount chiefs, 829 chiefs, and 7399 headmen/women in South Africa. The author divided the population of the former homelands (about 15 million) by the number of chiefs (830). Since there are 7400 headmen nationwide, the population per headman is over 2000 .
} 
have allowed mining companies to exploit mineral resources without consulting the locals and have monopolised the royalties obtained from the companies (Mnwana 2014). The Bafokeng people in the North West Province are the wealthiest tribe in South Africa due to their income from mines. However, the benefits accrued from such mining activity are not widely distributed among the locals. There is also a conflict among residents regarding the beneficiaries of such mining activity. Should the Bafokeng be the sole beneficiaries? Or should the non-Mfokeng, who live on the Bafokeng land, be included as well? (Comaroff and Comaroff 2009).

\section{Traditional Leadership and Rural Land Governance}

A brief review of land tenure reform policies of Zimbabwe, Namibia, and South Africa illustrates the striking similarities in the policies that they have adopted and introduced after independence. All three countries introduced legislation to identify and regulate the powers and authorities of traditional leaders. This indicates that the power and authority of traditional leaders are sanctioned by the central government, and statutory recognition is one of the sources of power and legitimacy for traditional leaders (Buthelezi and Skosana 2018). It also signifies that even if traditional leaders have the support of their own people, they may not be able to exercise certain powers unless they are recognised by the central government. This was demonstrated by the San traditional leadership case in Namibia. All three countries also introduced or amended the legislation concerning land in communal areas that gave traditional leaders the power to regulate the access to land in these areas. In the final section of this chapter, I will turn to some of the questions regarding the role of traditional leaders in rural land governance in these three countries - paying particular attention to their sources of power and legitimacy and their possible competitors.

\subsection{Popularity of Traditional Leadership: Resurgence, Tenacity, Reinvention}

When we talk about the popularity of traditional leadership in Africa from the end of the twentieth century to the early twenty-first century, one strand of literature emphasises its 'resurgence' or 'revival' due to the international political and economic climate of the 1990s. For instance, Oomen (2005), using South Africa as a case study, argued that when the democratisation of South Africa and the restoration of traditional leaders occurred during the 1990s, the importance of preserving and restoring cultural rights was emphasised through the rise of indigenous rights movements globally. In these international arenas, traditional leaders were seen as the embodiment of traditional culture, customs, and languages that were rapidly disappearing due to the wave of modernisation (Oomen 2005, 3-13). Comaroff and Comaroff $(2018,7)$ also 
pointed out the influence of neo-liberal policies, notably the decentralisation 'of the state and the outsourcing of many of its functions' or bypassing of its authorities by donors and corporations, on the resurgence of chiefship in several African countries.

This 'resurgent' aspect of traditional leadership is probably felt most strongly in South Africa, because well-developed scholarship has vehemently argued that there is no place for traditional leadership in a democratic South Africa. Perhaps the most well-known case was put forward by Mamdani (1996), who argued that the traditional leaders lost popular support due to the 'despotic' roles that they played during the apartheid regime and therefore had no place in a democratic South Africa. Ntsebeza (2005) also argued that traditional authority is incompatible with the democratic system, as the former relies on the hereditary system for choosing leaders. Another criticism came from civil society organisations, especially women's organisations, which indicated that women's rights were not sufficiently recognised under customary law (Amtaika 1996). Despite these criticisms, the South African Constitution (1996) recognised the traditional leaders and the TLGFA (2003) gave them a wide range of roles, which included rural land administration.

On the other hand, another strand of literature views the popularity of traditional leadership since independence as a result of the 'tenacity' of the institution, which has survived several shifts in political power from the colonial to the post-colonial period. There are at least two elements that explain the tenacity of traditional leadership. The first element applies to many other African countries as well, while the second is probably unique to or at least more prominent in the southern African region due to its colonial political economy. The former is the flexibility, versatility, or adoptability of African traditional leadership, which was articulated by Alexander (2018), who referred to Zimbabwe as her case study:

The 'return' of chiefs is a mirage, seemingly always sitting on the horizon. In fact, they never left. But their durability is not to do with staying the same: they have been as changeable and contradictory as state institutions themselves, always bound by the state's shifting demands and always rooted in versions of custom but never wholly defined by either of them. (Alexander 2018, 154)

In a similar vein, researchers also discuss the flexible nature of the 'customs', 'customary law', and 'customary' land tenure systems that are usually associated with traditional leadership. Distinguished from 'official' customary law, such as codified statutory laws during the colonial period and/or anthropologists' writings in the nineteenth and early twentieth centuries, several researchers advocated for the necessity of understanding the practices and norms that govern people's daily lives, which they termed as the 'living' customary law (Bennett 2004, 2008, 2009). The 'living' customary law is characterised by its flexibility and constant minor changes (Oomen 2005, 78). Thus, it is hard to grasp and even harder to incorporate into formal policy (Delius 2020). Cousins et al. (2011) argued that policymakers are hardly aware of the existence of the 'living' customary law. Consequently, they tend to rely on the customary laws of past times, which causes significant problems in the formulation of land tenure reform policies. Advocates of the 'living' customary law testify to the ever-changing nature of tradition and traditional leadership in Africa. 
The more southern Africa-specific source of tenacity of traditional leadership is concerned with the importance of the customary land tenure system for migrant workers and migrant sending societies. As often discussed in the classification of colonial rules in different parts of Africa, southern Africa was developed as labour reserves for settler-led economic development in the form of mines and commercial farms. In this colonial political economy model, African labourers in the mines, farms, and cities were considered temporary sojourners or migrants and were supposed to return to rural reserves once they retired or were no longer useful as a workforce. Native reserves were supposed to accommodate, nurture, and look after the people who were too young, old, sick, or frail to work in mines, farms, or cities (Wolpe 1972). In this context, a customary land tenure system controlled by traditional leadership served as a social safety net for migrants and migrant households by allowing them to retain their rights to the land in native reserves. As much as remittances were important for the daily survival of households in native reserves, remittance-sending migrants also needed to hold onto their land for retirement. Thus, O'Flaherty $(1998,544)$ argued that ' $[t]$ he crucial role played by the traditional political system in ensuring household survival may in part account for the widespread support for the traditional political system' that he observed in the south-eastern region of Zimbabwe. Mbiba (2001) corroborated the importance of the social security provided by customary tenure in communal areas for urban workers, but criticised it for being utilised as an excuse to curb the permanent settlement of Africans in urban areas in both colonial and post-colonial Zimbabwe.

I would like also to touch upon the 'reinvention' or 'restoration' of traditional leadership among the communities that had historically been known as more egalitarian or whose leadership structure was not recognised during the colonial period. In post-apartheid South Africa, the Khoisan people, ${ }^{5}$ whose ancestors were believed to be either decimated or integrated into the mixed population (called 'coloured' by apartheid racial classification) during the seventeenth and eighteenth century in the Dutch-ruled Cape colony, began to assert their indigenous Khoisan identity and called for the recognition of their leadership structures and demand for land. Their activism — often referred to as 'Khoisan revivalism' — intensified in the second decade of the twenty-first century (Sato 2018b) and culminated in the repeal of the TLGFA (2003) and the enactment of the Traditional and Khoi-San Leadership Act (2019). Their movement sought not only to restore their distinct cultural identity, but also demanded recognition from the South African state and the power and authority

\footnotetext{
${ }^{5}$ Khoisan is a general term used to refer to the pastoralist Khoikhoi and the hunter-gatherer San, who lived in southern Africa when Dutch settlers arrived in the seventeenth century. The San people were perceived as 'sub-human' by the colonialists and many of them were hunted down in the Cape colony. The Khoikhoi people were largely incorporated into the colonial economy as slaves and servants and were integrated into the mixed population through intermarriages (socalled 'coloured' in apartheid's racial classification). However, in post-apartheid South Africa, some people who used to be classified as 'coloured' began to identify themselves as Khoisan and demanded their recognition as an indigenous population. There are at least five groupings within Khoisan population in South Africa. They are Griqua, Koranna, Nama, Cape-Khoi, and San (Sato 2018b).
} 
that this recognition would bring to their leaders. Therefore, we need to shift our discussion to the relationship between traditional leaders and the state or the ruling party in these southern African countries.

\subsection{Chiefs, State/Ruling Party, and Rural Land Governance}

In terms of political system, while all three countries under discussion have multiparty electoral systems with different degrees of free and open competition, the politics of Zimbabwe, Namibia, and South Africa after independence are also characterised by the so-called dominant one-party rule that originated from their respective liberation movements. In this context, it is probably more appropriate to discuss traditional leaders' relationships with the dominant political party, rather than with the state itself. Several researchers, including those cited above (Alexander 2018; Gideon 2019), have suggested that Zimbabwe's ruling party, the ZANU-PF, wooed traditional leaders to their side in order to secure rural votes after they began to encounter significant electoral competition from the MDC. This scenario also applies to South Africa, where the African National Congress (ANC) faced fierce competition from the Inkatha Freedom Party (IFP) in the late 1990s. Before the nation's first democratic elections, the IFP was not only popular in the KwaZulu homeland-its original base, but also had many supporters in black urban townships in Gauteng Province, where many Zulu people lived. Although the ANC began to gain overwhelming support inside the country after the release of Nelson Mandela, the IFP's popularity was not shaken in rural KwaZulu. Since the IFP's popular support was believed to have been a result of its close relationship with the Zulu king and chiefs, the ANC hesitated to undermine traditional leaders when it came to power in 1994 (Amtaika 1996; Sato 2000; Beall et al. 2005).

Thus, traditional leaders are seen as voting banks by the ruling parties, even if this assertion may not have been tested scientifically. Nonetheless, the popularity of chiefs and their ability to influence rural voters was proven by a large-scale opinion survey in several African countries, including the three countries discussed here, albeit with major differences among the three. Using the data collected during the fourth round of the Afrobarometer survey that was conducted across 19 African countries in 2008 and 2009, Logan (2013, 354-355, 362-365) illustrated the startling intensity of support for traditional leadership in many countries across age, gender, educational level, and region of residence (rural vs. urban). However, popular support for traditional leadership differed among countries. Among the three discussed here, more Zimbabweans $(73 \%)$ said that their traditional leaders wielded significant influence, while this proportion was just below 50\% in Namibia and just over 30\% in South Africa. However, with respect to whether traditional leaders should have more influence in the local community, a greater percentage of Namibians $(60 \%)$ answered affirmatively, whereas Zimbabweans (51\%) and South Africans (34\%) were less enthusiastic about this proposition. Thus, it appears that traditional leaders in South Africa have 
the least influence over local communities and that the majority of local people are not keen to increase their influence.

A new question thus arises: Does the ruling party need traditional leaders or do traditional leaders need the ruling party or the state? This is not an easy question to answer, but there has been evidence that traditional leaders have actively engaged in politics by organising themselves and becoming politicians in South Africa (Oomen 2005, 95-98; Holomisa 2009, 2011). The most famous and influential association is the Congress of Traditional Leaders of South Africa (CONTRALESA). The CONTRALESA was formed in 1986 by traditional leaders who opposed the KwaNdebele homeland's 'independence' plan. During the period of political transition, it argued that the authority of traditional leaders under customary law should be recognised even after the transition to democracy. After democratisation, several chiefs, including Phathekile Holomisa-the former chairperson of the CONTRALESAand Mandla Mandela-Nelson Mandela's grandchild-continued to influence the policy formation process as members of Parliament from the ruling ANC (Sato 2018a). The chiefs' lobbying activities appear to be stronger in South Africa than in Zimbabwe and Namibia, which seems to suggest that traditional leaders need more state recognition and support in South Africa since they have the least influence on and popularity among local communities. Berry (2018) argued that South African chiefs have to rely on the state to legitimise their power and authority because they have lost their control over the territory and material resources under settler colonialism.

The analysis of the Afrobarometer survey (Logan 2013) also reveals that popular support for traditional leaders arises not only based on who they are, but also what they actually do. This point was illustrated by Mkodzongi (2016) using a Zimbabwean example. He discussed the rivalry between local chiefs and the central state over the benefits accrued from platinum mines in the context of the indigenisation policy in Mashonaland West Province. The local chiefs, who 'instrumentalised their position as 'representatives' of their ancestors', and the 'ZANU-PF government ministers' tried to control the community trust that would become local shareholders of the mining company. In this conflict between the local chiefs and the ZANU-PF politicians, the latter were perceived as 'outsiders'. The locals thus rallied behind the chiefs to ensure that they would benefit from the mine (Mkodzongi 2016, 103, 107-110). Alexander (2018, 141-143) also stated that the failure of the VIDCOs and WADCOs in the 1980s stemmed from the fact that these local institutions were given the task of implementing the unpopular policies of the central government. When the interests of the central government and those of local communities are incompatible, the locals support the voices that represent local interests. Traditional leaders have served as such voices in several places.

In South Africa and Namibia, the traditional authority was the local government in their homelands during the colonial and apartheid periods. While it was possible that they governed people in a 'despotic' way (Mamdani 1996), other research has argued that chiefs had to rely on support from residents to function as local governments in situations where they did not have sufficient administrative or financial support from the homeland governments. McIntosh (1992) argued that chiefs acquired a 
certain degree of legitimacy through this process. Murisa $(2013,256)$ also stated that in Zimbabwe

[t]he enduring popularity of the office of chief among people derived from the fact that, despite the overt attempts at co-option by the [colonial] state and the lack of explicit coercion, the former maintained a form of independence and autonomy in articulating the interests of the subject communities.

After independence, the system of electing local leaders through a democratic method was also introduced in southern African countries. Therefore, theoretically, local governments or elected local councillors should be able to represent local voices against the central government if the latter wants to intervene in a manner that might damage the local communities. However, there are many examples of inefficient local governments that cannot fulfil their expected roles with respect to the provision of public services. Problems with corrupt local councillors are frequently reported in the media in South Africa (Ainslie and Kepe 2016). Interestingly, the Afrobarometer survey also reported that people do not necessarily view traditional leadership and local government as competing institutions. According to Logan (2013, 367-368), 'those who trust traditional leaders are also more likely to trust their local councillors' . Moreover, she stated that 'people regard [traditional leaders] as markedly better listeners' and this is their 'greatest apparent advantage over local councillors'. In principle, people appear to be more concerned with whether leaders care about them and whether they display accountability to the local people.

Nonetheless, not all traditional leaders care equally for the people they claim to represent or are capable of managing access to land in a manner that would benefit local people. Even though the central government of all three countries bestowed the power and authority over rural land administration to traditional leaders, this does not mean that their authority is uncontested. I have discussed this notion in Sect. 2, especially in the case of South Africa. Additionally, the system of rural land governance by traditional leaders in communal areas is not free from problems, as was demonstrated through the aforementioned Namibian case. Traditional leaders are not immune to modern sources of corruption, such as wealthy or well-connected individual farmers who want to monopolise communally owned resources for their own interests. Some of them even use their state-sanctioned land administration power to enrich themselves without sharing the benefits obtained from the land with their people. Moreover, according to popular opinion, land allocation is not the top responsibility of traditional leaders. In the Afrobarometer survey, fewer than $30 \%$ of respondents stated that traditional leaders should bear the primary responsibility for this task (Logan 2013, 360). Therefore, when it comes to rural land governance, we should also consider alternatives to land allocation by traditional leaders. The community conservancy developed in Namibia serves as an alternative that might effectively defend communal lands against encroachment by wealthy farmers. ${ }^{6}$

\footnotetext{
${ }^{6}$ The management of natural resources such as wildlife by rural communities is not unique to Namibia, but it has been widely promoted and adopted in the southern African region since late 1980s, as evidenced by Zimbabwe's CAMPFIRE programme (Balint and Mashinya 2008; Tchakatumba et al. 2019). It was originally devised to manage the conflicts between the human and wildlife
} 
In Namibia, community conservancy is regulated through the Nature Conservation Amendment Act (1996). The Act intends to partially decentralise wildlife management to local communities who organise themselves as a conservancy entitled to the profits accrued from wildlife through tourism ventures, such as safari camps and trophy hunting (Jones 2010). Since the first conservancy was established in 1998, the number of registered conservancies increased to 29 in 2003-covering $25 \%$ of the total communal area (Lankhorst 2009, 210-211). By 2017, the number of conservancies increased to 83 and more than half of communal areas became community conservancies or community forests (Gargallo 2020, 132). However, apart from a small number of conservancies that became popular tourist attractions, most of them only generate marginal revenues for local communities. Despite this, conservancies were continually established, apparently because communities saw them as a means to strengthen their land claims. Since establishing a conservancy entails defining its boundaries and membership, people view it as a means 'to keep outsiders out' and to prevent the enclosure of grazing lands by wealthy individuals in communal areas. Lankhorst $(2009,211-212)$ argued that conservancies could bear a particular appeal for the San people to secure their lands, as most of their leadership were not recognised by the Traditional Authorities Act (2000).

However, not all researchers share this optimism regarding community conservancies. Lapeyre $(2010,96)$ discussed a case where outside farmers grazed their livestock in the section of conservancy that was meant to be used for tourism and was leased out to a private company. Since this act was not illegal and was recognised as their 'customary right', the private company could not unilaterally remove the concerned livestock. Moreover, conservancies are not free from a chiefly influence. There are cases where traditional authorities have tried to control the management committees of conservancies or to secure benefits accruing from conservation-related activities. In addition, members of conservancies may not be able to agree on the land use plans. Some may want to use the land for agricultural purposes, whereas others may want to utilise it for grazing or tourism. In most conservancies, members need to demarcate areas to be used for different purposes such as hunting, tourism and livestock grazing, but agreeing on these land use plans is often difficult (Gargallo 2020, 138-140). Thus, community conservancies still entail certain complicated group dynamics of communal land management.

\section{Conclusion}

In the conclusion, I would like to return to the fundamental question of land tenure reform that was formulated in the South African White Paper on Land Policy, but which should also apply to Namibia and Zimbabwe. In its present form, is the customary land tenure system able to strengthen the land rights of residents

populations. However, what is unique to Namibia is that rural people began to use the concept of community conservancy to prevent the enclosure of communally-held resources by rich farmers. 
in the communal areas of these southern African countries? In other words, does the customary tenure system offer a real alternative to the freehold tenure system? (Beinart et al. 2017, 48). Reviewing relevant literature on land tenure reform in these three countries has revealed that the principal contentions surrounding it are related to identifying the appropriate entity to administer the communal land and whether traditional leaders should continue to regulate the access to land, albeit under some degree of supervision by state institutions such as land boards and district councils. Evidently, there are cases where traditional leaders have demonstrated ineffective oversight and control over the access to land, especially grazing lands. This was particularly observed in Namibia, where wealthy and well-connected ranchers either defied or corrupted traditional leaders and privatised communal resources. In Zimbabwe, some traditional leaders, especially sabhukus, sold pieces of grazing land to newcomers for residential and agricultural purposes. Although this may be viewed as a 'traditional' practice, and not all sabhukus charge exorbitant fees, it can be argued that traditional leaders undermine the locals' future land needs by selling it to outsiders and that some leaders sell land for personal gain.

Some forms of alternative institutions have been proposed, such as a land management committee that is independent of traditional authorities in South Africa and community conservancies in Namibia. However, there is no guarantee that these alternatives will manage communally held resources more effectively. The administration of communal lands will always be a complicated process-regardless of who is selected to do it-due to the group dynamics, different demands for land usage, and the issue of autochthony and migrants. This is particularly true in the context of the increasing scarcity of land in communal areas due to the increase in the number of both population and livestock, which is a result of a natural increase and/or in-migration. Unless the total landmass is enlarged through land redistribution programmes, land management in communal areas will only increase in difficultyespecially in Namibia and South Africa-where land redistribution has progressed in a slow and limited manner.

Thus, I would argue that rather than focussing on traditional leaders, we need to go back to the debates on the role of customary land tenure as social security, even though these two debates have been historically interconnected. In Zimbabwe and in parts of South Africa, the attempts by the colonial and apartheid governments to introduce individual tenure in order to create full-time 'master farmers' in native reserves was met with fierce opposition (Beinart 1984; Alexander 2006). Rural people opposed it because this modernisation programme entailed other measures to make their agricultural practices more conservation-friendly, such as the forced culling of livestock and back-breaking contour construction. Urban migrant workers opposed it because they feared losing their rights to land in rural areas, which acted as a safety net for them. These developments occurred in the 1950s. The question is, are the political economies of southern African countries still characterised by predominantly temporary migration from rural areas to mines, farms, or urban areas? Unless we address the migrants' fear of losing their stakes in rural areas, they will keep relying on rural areas for their social security needs. In other words, we need alternative forms of social security to customary land tenure for urban workers and 
city dwellers, so as to relieve the pressure on rural land. Once that is achieved, better ways of managing land in rural areas can be discussed.

\section{References}

Adams, M., and R. Knight. 2012. Land policy developments and setbacks in southern Africa. In Southern African development community land issues: Towards a new sustainable land relations policy, ed. B. Chigara, 27-56. London and New York: Routledge.

Ainslie, A., and T. Kepe. 2016. Understanding the resurgence of traditional authorities in postapartheid South Africa. Journal of Southern African Studies 42 (1): 19-33.

Alexander, J. 2006. The unsettled land: State-making and the politics of land in Zimbabwe 18932003. Oxford: James Currey.

Alexander, J. 2018. The politics of states and chiefs in Zimbabwe. In The politics of custom: Chiefship, capital, and the state in contemporary Africa, ed. J.L. Comaroff and J. Comaroff, 134-161. Chicago and London: The University of Chicago Press.

Aliber, M., T. Maluleke, T. Manenzhe, G. Paradza, and B. Cousins. 2013. Land reform and livelihoods: Trajectories of change in Northern Limpopo province, South Africa. Cape Town: HSRC Press.

Amoo, S.K., and S.L. Harring. 2012. Property rights and land reform in Namibia. In Southern African development community land issues: Towards a new sustainable land relations policy, ed. B. Chigara, 222-262. London and New York: Routledge.

Amtaika, A.L. 1996. The role of tribal authorities in a democratic KwaZulu-Natal. M.sc. Thesis. Department of Political Studies, University of Natal.

Andersson, J.A. 1999. The politics of land scarcity: Land disputes in Save communal area Zimbabwe. Journal of Southern African Studies 25 (4): 553-578.

Balint, P.J., and J. Mashinya. 2008. CAMPFIRE through the lens of the 'commons' literature: Nyaminyami rural district in post-2000 Zimbabwe. Journal of Southern African Studies 34 (1): 127-143.

Beall, J., S. Mkhize, and S. Vawda. 2005. Emergent democracy and 'resurgent' tradition: Institutions, chieftaincy and transition in KwaZulu-Natal. Journal of Southern African Studies. 31 (4): 755 771.

Beinart, W. 1984. Soil erosion, conservationism and ideas about development: A southern African exploration, 1900-1960. Journal of Southern African Studies 11 (1): 52-83.

Beinart, W., P. Delius, and M. Hay. 2017. Rights to land: A guide to tenure upgrading and restitution in South Africa. Auckland Park: Fanele.

Bennett, T.W. 2004. Customary law in South Africa. Lansdowne: Juta.

Bennett, T.W. 2008. 'Official' vs 'living' customary law: Dilemmas of description and recognition. In Land, power and custom: Controversies generated by South Africa's communal land rights act, ed. A. Claassens and B. Cousins, 138-153. Cape Town: UCT Press.

Bennett, T.W. 2009. Re-introducing African customary law to the South African legal system. The American Journal of Comparative Law 57 (1): 1-31.

Berry, S. 2018. Chieftaincy, land, the state in Ghana and South Africa. In The politics of custom: Chiefship, capital, and the state in contemporary Africa, ed. J.L. Comaroff and J. Comaroff, 79-109. Chicago and London: The University of Chicago Press.

Bruce, J.W., and A. Knox. 2009. Structures and stratagems: Making decentralization of authority over land in Africa cost-effective. World Development 37 (8): 1360-1369.

Buthelezi, M., and D. Skosana. 2018. The salience of chiefs in postapartheid South Africa: Reflections on the Nhlapo commission. In The politics of custom: Chiefship, capital, and the state in contemporary Africa, ed. J.L. Comaroff and J. Comaroff, 110-133. Chicago and London: The University of Chicago Press. 
Chamunogwa, A. 2019. The negotiability of state legal and bureaucratic authority during land occupations in Zimbabwe. Review of African Political Economy 46 (159): 71-85.

Cheater, A. 1990. The ideology of 'communal' land tenure in Zimbabwe: Mythogenesis enacted? Africa 60 (2): 188-206.

Chimhowu, A., and P. Woodhouse. 2008. Communal tenure and rural poverty: Land transactions in Svosve communal area Zimbabwe. Development and Change 39 (2): 286-308.

Chimhowu, A., and P. Woodhouse. 2010. Forbidden but not suppressed: A 'vernacular' land market in Svosve communal lands Zimbabwe. Africa 80 (1): 14-35.

Claassens, A. 2008. Power, accountability and apartheid borders: The impact of recent laws on struggles over land rights. In Land, power and custom: Controversies generated by South Africa's communal land rights act, ed. A. Claassens and B. Cousins, 262-292. Cape Town: UCT Press.

Claassens, A., and D. Gilfillan. 2008. The Kalkfontein land purchases: Eighty years on and still struggling for ownership. In Land, power and custom: Controversies generated by South Africa's communal land rights act, ed. A. Claassens and B. Cousins, 295-314. Cape Town: UCT Press.

Comaroff, J.L., and J. Comaroff. 2009. Ethnicity, inc. Scottsville: University of KwaZulu-Natal Press.

Comaroff, J.L., and J. Comaroff. 2018. Chief, capital, and the state in contemporary Africa: An introduction. In The politics of custom: Chiefship, capital, and the state in contemporary Africa, ed. J.L. Comaroff and J. Comaroff, 1-48. Chicago and London: The University of Chicago Press.

Cousins, B. 2008. Contextualising the controversies: Dilemmas of communal tenure reform in postapartheid South Africa. In Land, power and custom: Controversies generated by South Africa's communal land rights act, ed. A. Claassens and B. Cousins, 3-31. Cape Town: UCT Press.

Cousins, B., R. Alcock, N. Dladla, D. Hornby, M. Masondo, G. Mbatha, M. Mweli, and C. Alcock. 2011. Imithetho yomhlaba yaseMsinga: The living law of land in Msinga, KwaZulu-Natal. Research report 43. Cape Town: PLAAS, University of the Western Cape.

Cousins, B., D. Weiner, and N. Amin. 1992. Social differentiation in the communal lands of Zimbabwe. Review of African Political Economy 53: 5-24.

Dande, I., and J. Mujere. 2019. Contested histories and contested land claims: Traditional authorities and the fast track land reform programme in Zimbabwe, 2000-2017. Review of African Political Economy 46 (159): 86-100.

Delius, P. 2020. Chiefly succession and democracy in South Africa: Why history matters. Journal of Southern African Studies. https://doi.org/10.1080/03057070.2021.1855042.

Department of Land Affairs, South Africa (DLA). 1997. White paper on South African land policy. Pretoria: Department of Land Affairs.

Financial and Fiscal Commission, South Africa (FFC). 2016. FFC submission on the traditional and Khoi-San leadership bill. PowerPoint presentation to the public hearings on the traditional and Khoi San leadership bill, February 2. www.ffc.co.za/media-events/presentations. Accessed February 26, 2016.

Fontein, J. 2009. 'We want to belong to our roots and we want to be modern people': New farmers, old claims around lake Mutirikwi, southern Zimbabwe. African Studies Quarterly 10 (4): 1-34.

Gargallo, E. 2020. Community conservation and land use in Namibia: Visions, expectations and realities. Journal of Southern African Studies 46 (1): 129-147.

Gideon, C. 2019. Land reform and the calculus for power in Zimbabwe's democratic transition. In Trajectory of land reform in post-colonial African States: the quest for sustainable development and utilization, ed. A.O. Akinola and H. Wissink, 13-27. Cham: Springer.

Goodwin, D. 2013. Whatever it takes: Tenure security strategies of communal land right holders in Zimbabwe. Africa 83 (1): 164-187.

Hall, R. 2003. A comparative analysis of land reform in South Africa and Zimbabwe. In Unfinished business: The land crisis in Southern Africa, ed. Margret C. Lee and K. Colvard, 255-285. Pretoria: Africa Institute of South Africa.

Holomisa, S.P. 2009. According to tradition: A cultural perspective on current affairs. Somerset West: Essential Books. 
Holomisa, S.P. 2011. A double-edged sword: A quest for a place in the African sun, 3rd ed. Houghton: Real African Publishers (First published in 2007 by Lotsha publications and booksellers).

Jones, B. 2010. The evolution of Namibia's communal conservancies. In Community rights, conservation and contested land: The politics of natural resources governance in Africa, ed. F. Nelson, 106-120. London and Washington, DC: Earthscan.

Lankhorst, M. 2009. Land tenure reform and tenure security in Namibia. In Legalising land rights: Local practices, state responses and tenure security in Africa, Asia and Latin America, ed. J.M. Ubink, A.J. Hoekema, and W.J. Assies, 193-215. Leiden: Leiden University Press.

Lapeyre, R. 2010. The conflicting distribution of tourism revenue as an example of insecure land tenure in Namibian communal lands. In The struggle over land in Africa: Conflicts, politics and change, ed. W. Anseeuw and C. Alden, 85-103. Cape Town: HSRC Press.

Logan, C. 2013. The roots of resilience: Exploring popular support for African traditional authorities. African Affairs 112 (448): 353-376.

Mamdani, M. 1996. Citizen and subject: Contemporary Africa and the legacy of late colonialism. New Jersey: Princeton University Press.

Mbiba, B. 2001. Communal land rights in Zimbabwe as state sanction and social control: A narrative. Africa 71 (3): 426-448.

McIntosh, A.C. 1992. Options for rural local government and administration in South Africa with particular reference to KwaZulu. Investigational Report No 75. Pietermaritzburg: Institute of Natural Resources, University of Natal.

Mkodzongi, G. 2016. 'I am a paramount chief, this land belongs to my ancestors': The reconfiguration of rural authority after Zimbabwe's land reforms. Review of African Political Economy 43 (sup1): 99-114.

Mkodzongi, G. 2018. 'We won't have Zim-style land grabs': What can South Africa learn from Zimbabwe's fast-track land reforms? In Land reform revisited: Democracy, state making and agrarian transformation in post-apartheid South Africa, ed. F. Brandt and G. Mkodzongi, 172195. Leiden and Boston: Brill.

Mnwana, S. 2014. Chief's justice? Mining, accountability and the law in the Bakgatla-ba-Kgafela traditional authority area. South African Crime Quarterly 49 (September): 21-29.

Moyo, S. 2007. The land question in southern Africa: A comparative perspective. In The land question in South Africa: The challenge of transformation and redistribution, ed. L. Ntsebeza and R. Hall, 60-84. Cape Town: HSRC Press.

Moyo, S. 2013. Land reform and redistribution in Zimbabwe since 1980. In Land and agrarian reform in Zimbabwe: Beyond white-settler capitalism, eds. S. Moyo and W. Chambati, 29-77. Dakar: CODESRIA.

Murisa, T. 2013. Social organisation in the aftermath of 'fast track': An analysis of emerging forms of local authority, platforms of mobilisation and local cooperation. In Land and agrarian reform in Zimbabwe: Beyond white-settler capitalism, eds. S. Moyo and W. Chambati, 251-289. Dakar: CODESRIA.

Murisa, T. 2014. Democratisation and control: Fast track and local government reforms in Zimbabwe. Journal of Contemporary African Studies 32 (1): 79-99.

Murombedzi, J.C. 2010. Agrarian social change and post-colonial natural resource management interventions in southern Africa's 'communal tenure' regimes. In Community rights, conservation and contested land: The politics of natural resources governance in Africa, ed. F. Nelson, 32-51. London and Washington, DC: Earthscan.

Murray, C., and R. Stacey. 2008. Tagging the bill, gagging the provinces: The communal land rights act in parliament. In Land, power and custom: Controversies generated by South Africa's communal land rights act, ed. A. Claassens and B. Cousins, 72-91. Cape Town: UCT Press.

National Land Committee. 1994. Report from the community land conference, 12 \& 13 February 1994. Johannesburg: National Land Committee.

North Gauteng High Court. 2009. Tongoane and others v National minister for agriculture and land affairs and others (11678/2006) [2009] ZAGPPHC 127; 2010 (8) BCLR 828 (GNP). www.saf lii.org/za/cases/ZAGPPHC/2009/127.html. Accessed 25 December 2015. 
Ntsebeza, L. 2005. Democracy compromised: Chiefs and the politics of land in South Africa. Leiden: Brill.

Odendaal, W.A. 2010. A legal analysis of the Namibian commercial agricultural land reform process. In The struggle over land in Africa: Conflicts, politics and change, ed. W. Anseeuw and C. Alden, 193-206. Cape Town: HSRC Press.

O'Flaherty, M. 1998. Communal tenure in Zimbabwe: Divergent models of collective land holding in the communal areas. Africa 68 (4): 537-557.

Oomen, B. 2005. Chiefs in South Africa: Law, power and culture in the post-apartheid era. Oxford: James Currey.

Peires, J. 2014. History versus customary law: Commission on traditional leadership: Disputes and claims. South African Crime Quarterly 49: 7-20.

Sato, C. 2000. The prospect of land reform and rural restructuring in post-apartheid South Africa. $\mathrm{Ph}$.D. Thesis, Department of International Relations, Ritsumeikan University, Kyoto, Japan (in Japanese with English abstract).

Sato, C. 2018a. Land tenure reform in South Africa: Traditional leadership, CLaRA, and 'living' customary law. In Development, migration, and resources in Africa, eds. H. Kirikoshi, Y. Matsunami, and S. Takeuchi, 103-121. ASC-TUFS Working Papers 2018. Tokyo: African Studies Center, Tokyo University of Foreign Studies.

Sato, C. 2018b. Khoisan revivalism and land question in post-apartheid South Africa. In Land reform revisited: Democracy, state making and agrarian transformation in post-apartheid South Africa, eds. F. Brandt and G. Mkodzongi, 199-220. Leiden and Boston: Brill.

Scoones, I., N. Marongwe, B. Mavedzenge, J. Mahenehene, F. Murimbarimba, and C. Sukume. 2010. Zimbabwe's land reform: Myth and realities. Suffolk: James Currey.

Tchakatumba, P.K., E. Gandiwa, E. Mwakiwa, B. Clegg, and S. Nyasha. 2019. Does the CAMPFIRE programme ensure economic benefits from wildlife to households in Zimbabwe? Ecosystem and People 15 (1): 119-135.

Werner, W. 1993. A brief history of land dispossession in Namibia. Journal of Southern African Studies 19 (1): 135-146.

Williams, G. 1996. Setting the agenda: A critique of the World Bank's rural restructuring programme for South Africa. Journal of Southern African Studies 22 (1): 139-166.

Williams, J.M. 2009. Legislating 'tradition' in South Africa. Journal of Southern African Studies 35 (1): 191-209.

Wolpe, H. 1972. Capitalism and cheap labour-power in South Africa: From segregation to apartheid. Economy and Society 1 (4): 425-456.

Zondi, S. 2003. Land reform in Namibia in the context of the Zimbabwean crisis: A regional perspective. In Unfinished business: The land crisis in southern Africa, eds. M.C. Lee and K. Colvard, 317-349. Pretoria: Africa Institute of South Africa.

Open Access This chapter is licensed under the terms of the Creative Commons Attribution 4.0 International License (http://creativecommons.org/licenses/by/4.0/), which permits use, sharing, adaptation, distribution and reproduction in any medium or format, as long as you give appropriate credit to the original author(s) and the source, provide a link to the Creative Commons license and indicate if changes were made.

The images or other third party material in this chapter are included in the chapter's Creative Commons license, unless indicated otherwise in a credit line to the material. If material is not included in the chapter's Creative Commons license and your intended use is not permitted by statutory regulation or exceeds the permitted use, you will need to obtain permission directly from the copyright holder.

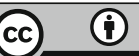

